\title{
Beyond Skill Instruction: Promoting Literacy Acquisition in Kindergarten
}

\author{
Kerry P. Laster \\ Caddo Parish School Board, Louisiana \\ 920 East 70th Street, Shreveport, LA 71106, USA
}

Tel: 1-318-868-4425 E-mail: thereadingctr@bellsouth.net

Evan T. Ortlieb (corresponding author)

Dept. of Early Childhood, Valdosta State University

1500 N Patterson St, Valdosta, GA 31698, USA

Tel: 1-229-333-5641_E-mail: etortlieb@valdosta.edu

Earl H. Cheek, Jr.

Dept. Chair of Educational Theory, Policy, and Practice

Louisiana State University - Baton Rouge

223 Peabody Hall, Baton Rouge, LA 70803, USA

Tel: 1-225-578-6867_E-mail: echeek@lsu.edu

\begin{abstract}
It is well-known that kindergarten teachers provide diverse opportunities for early literacy development; however, there are many aspects to literacy instruction at the kindergarten level that have not been thoroughly researched (Harris, Loyo, Holahan, Suzuki, \& Gottlieb, 2007). Moreover, a diminutive amount of evidence exists about the role of contextual variables related to the classroom teacher (Richman \& Colombo, 2007). As a result, an in-depth investigation was designed to study one successful kindergarten teacher, her behaviors, and her effect on students as they developed early literacy skills.

By describing one highly regarded kindergarten teacher, this research investigation supplies valuable insight into classroom teaching with implications for schools seeking improvement in their development of early literacy skills for kindergarteners. Through examining each aspect of this teacher's behavior, instructional practices, and her classroom environment, pertinent information regarding promoting early literacy acquisition can be revealed.
\end{abstract}

Keywords: Kindergarten, Literacy, Reading, Acquisition, Early childhood, Teacher 


\section{Introduction}

The focal point in early educational development is no longer first grade-it is kindergarten! Today, most kindergarten classes are no longer part-time, play-oriented introductory school experiences, but rather "real school" (Morris, Bloodgood, Lomax, \& Perney, 2003). Developmentally appropriate practices where students are engaged in reading and writing designed to foster emergent literacy skills are not only required in most cases, but also particularly salient (Charlesworth, 1998a; Charlesworth, Hart, Burts, \& DeWolf, 1993; Huffman \& Speer, 2000; Marcon, 2002; Neuharth-Pritchett, 2001; Parker \& Neuharth-Pritchett, 2006; Torgesen, 2004). With the advent of higher accountability and expectations, more academic productivity is compulsory of young children in kindergarten classrooms. Yet, numerous studies have determined that there is a discrepancy between the daily classroom practices of kindergarten teachers and their beliefs about developmentally appropriate practices for young children (Chang, 2003; McMullen, 1999).

The development of appropriate curricula does not guarantee student success; it is the teacher's facilitation of those learning objectives that fosters academic achievement (Justice, Mashburn, Hamre, \& Paianta, 2008). Teachers' beliefs and attitudes strongly influence their instruction and thus, have both direct and indirect impacts on children's educational outcomes (Fang, 1996; Vartuli, 1999). Behavioral styles as well as responses to behavior are also closely related to these teacher beliefs (Muijs \& Reynolds, 2002). Moreover, Arbeau and Coplan (2007) affirm that “teachers' belief systems contribute towards children's acquisition of knowledge, serve to provide children with rules, generate a climate for learning, and directly influence students’ behaviors towards peers” (pp. 291-92).

All of these factors are part of a larger framework of understanding the teacher-child relationship. Effective teacher-child relationships can create improved social and academic outcomes. In classrooms where there are positive teacher-child relationships, children can more easily adjust to the school environment and as a result, have more advantageous school-appropriate behaviors (Birch \& Ladd, 1997; Hamre \& Pianta, 2001). This study aims to provide additional insight and clarity on the subject of early literacy acquisition as it pertains to a kindergarten teacher's beliefs and instructional delivery.

\section{Purpose of Study}

This research venture examines the characteristics of one successful kindergarten teacher, her behaviors, and her interactions with students as they acquired early literacy skills. This teacher was employed in an inclusive setting, where such developmentally appropriate activities as the repeated read aloud strategy were used as the foundation to cultivate early literacy skills. The present study was not designed to present any cause-effect relationship between teacher behaviors and student outcomes; rather its purpose was to investigate the relationship and establish correlations between specific teacher practices and student literacy acquisition.

By presenting an in-depth description of one successful kindergarten teacher, this research exploration provides valuable insight into classroom reading instruction beyond the areas of reading recognized by the National Reading Panel in 2000. Explicit information discussed 
depicts methods of extending reading instruction to reach all learners with potential implications for school programs committed to the development of early literacy skills for kindergarteners. Knowledge of effective practices may help alleviate the failures of kindergarten students in regard to early literacy acquisition (Rimm-Kaufman, La Paro, Downer, \& Pianta, 2005).

\subsection{Research Questions}

The present study focuses on four aspects of teacher behavior as they relate to early literacy development:

1) What was the interaction of the teacher with the kindergarteners?

2) What behaviors did the teacher exhibit to engage students in the literacy processes of reading and writing?

3) What behaviors did the teacher exhibit to encourage student reactions to books using specific strategies like the repeated read aloud?

4) What were the professional activities and interactions of the classroom teacher with her peers that contributed to her beliefs and practices?

\section{Best Practices}

In the early years of school, it is especially important for teachers to establish a structural foundation for literacy (Stahl, 2006). Areas that contribute to the development of automatic word identification include phonemic awareness, phonics, and fluency (Fox, 2007; Metsala \& Ehri, 1998; Strickland, 2001). The National Reading Panel (2000) found that explicit instruction of phonemic awareness led to improvements in multiple areas of reading, including phonemic awareness, oral reading, and spelling (Byrne \& Fielding-Barnsley, 1991, 1993, 1995, 2000). When combined with letter-sound correspondence, teaching phonemic awareness was more effective in improving reading ability (Hatcher, Hulme, \& Ellis, 1994; Neuman \& Dickinson, 2003; Schneider, Roth, \& Ennemoser, 2000). Systematic phonics instruction was also deemed more effective than alternate approaches that deemphasized phonics as a core component of reading instruction.

Fluency can be developed through a number of teaching strategies as well as simply modeling appropriate pace and expression (Rasinsky, Blachowicz, \& Lems, 2005). Allowing kindergarten students to echo and chorally read with the classroom teacher gives them confidence and voice within daily activities, setting the stage for independent reading. Shared reading using big books, sentence strips, and stories on chart paper, transparencies, or electronic Smart Boards/ACTIVboards can further promote fluency, as the teacher or student tracks the words and reads aloud (McGee \& Morrow, 2005; Woude, 2004).

The other major area of focus is reading comprehension, as children begin to associate meaning with text. Both vocabulary and comprehension strategies should be utilized to develop students' comprehension abilities, as there is a close relationship between these two sub-areas of reading. At the kindergarten level, it is commonplace for vocabulary to be 
introduced prior to reading as well as through repetition and multiple exposures (Kamil \& Hiebert, 2005). Providing a rich context can also set the stage for incidental learning of new words (Biemiller \& Boote, 2006).

To address comprehension development, a mixed approach of multiple comprehension strategies is advocated (Williams, 2002). Through teaching story structure, summarization, self-monitoring, visualization, and other research-based strategies, kindergarten teachers provide students with necessary foundational skills to be successful in future grade levels. Of the methods available to kindergarten teachers, there are few that match the effectiveness of appropriately utilizing read alouds within a reading program (Allor \& McCathren, 2003). The wide-ranging benefits include letter and sound connections and other concepts about print, vocabulary acquisition, knowledge of story structure, demonstrating reading processes in context, and modeling interest and fluency (Rog, 2001). Simply immersing students in various types of print, however, will not contribute to their reading development; there has to be a purpose for the reading. Students must reflect on what is on the page and relate it to their lives and experiences so as to make connections to the print. Teale and Yokota (2000) emphasize three key components of effective read-alouds: 1) selecting high-quality literature that extends worldly knowledge; 2) students must be active and critically thinking; and 3) rereading of familiar texts.

\section{Methods}

\subsection{Research Design}

A descriptive single case study of one successful teacher was conducted in a developmental kindergarten classroom with regular education and special education students at a public elementary school in a southern school district. A qualitative research design was selected for the present study because (a) it was conducted in a natural setting and the researchers' insights were central to the analysis; (b) it was descriptive, and the data were collected in the form of words or pictures; (c) the investigator was concerned with a process rather than simply a product; (d) data were analyzed inductively as themes and patterns emerged; and (e) meaning was at the center of this approach (Bogdan \& Biklen, 2006). A single case study format was used because the purpose was to gather comprehensive, systematic, and in-depth information about an effective kindergarten teacher.

The investigation of teacher behaviors and student acquisition of early literacy skills in a developmentally appropriate kindergarten classroom took place over duration of seven months. The primary investigator observed this kindergarten classroom two to five times per week for two or more hours per visit. The time of day was varied so that different types of activities could be observed. Based on Spradley's (1980) research methods and strategies, participant observation was the primary mode used to gain information and access data in this environment. Conversations with the regular kindergarten classroom teacher and the full inclusion special education teacher provided a broader knowledge of the ongoing activities being observed (Owocki \& Goodman, 2002). Key informants such as the school administrators, curriculum coordinator, and four other kindergarten teachers were used to provide a more thorough understanding of the students, teacher, and learning environment. 


\subsection{Selection of Participant}

The classroom teacher, identified as Ms. May to preserve anonymity, was selected as the subject of this research because she was the most-recognized kindergarten teacher in the district over her tenure of 27 years. Her achievements include twice being recognized as teacher of the year, and in addition, she provides a leadership role in the professional development of her fellow kindergarten teachers in the district. Ms. May is highly regarded and viewed as outstanding by her peers, administration, and parents in the community.

\subsection{Data Collection/Analysis}

Taking detailed field notes of classroom interactions and teacher behavior consisted of two types of information: descriptive and reflective. As a participant observer, a textual picture of the setting, teacher, students, and other adults was captured. The researcher observed actions and conversations and assimilated them as part of the field notes. Transcriptions of tape recordings also allowed the investigator to depict classroom occurrences to a greater extent.

The data were analyzed according to qualitative methods using the constant comparative method of data analysis. Patton (2001) stated that analysis of data requires a review of all field notes, organization of the data, and study for emergent themes and linkages between patterns in the data. The constant comparative method involves a series of actions that occur simultaneously with the analysis routinely recurring to involve more data collection and coding. Glaser (as cited in Bogdan \& Biklen, 2006) described the following steps involved in the constant comparative method: (a) start data collection, (b) search for key issues, events, and activities within the data to develop categories of focus, (c) collect additional data that provide examples of the categories of focus, (d) write about the categories by attempting to describe and account for the examples in the data while constantly looking for new examples, (e) work with the data and emerging themes to discover basic relationships, and (f) gather samples, code, and write as the analysis focuses on the primary categories. In the beginning stages of the research, classroom data were collected and some initial coding was completed to look for emerging themes (e.g., regular use of read alouds, integration of literacy across the content areas, variety of interactive literacy activities throughout the day). Frequently revisiting the classroom allowed for collection of more data, completion of further analysis, and a search for linkages between the data in a complex recursive activity, which culminated in this research report.

The coded data were analyzed and sorted between frequently occurring events (e.g., writing activities within centers) and infrequently occurring events (e.g., peer-to-peer reading). Data from the field notes, interviews, and student records were reviewed routinely to search for recurring patterns and emergent themes, allowing for data triangulation. As patterns emerged, sources were rechecked to confirm or deny the patterns. Every attempt was made to review and synthesize all information gained from the field notes and interviews to complete this study. Through this process, a rich descriptive picture emerged, depicting how this kindergarten teacher fostered early literacy acquisition within her students.

\section{Results}




\subsection{The Classroom Community}

The classroom was a constant hum of noise. The investigator initially noted, "There are movement and a small amount of noise, but to an outside observer who had not been a part of this entire activity this would probably look like a class in chaos.” Students were moving around the room, negotiating their classroom environment in productive ways. To understand the classroom community, one must understand the routines, physical environment, and teacher practices which resulted in the students successfully acquiring early literacy skills. Ms. May's classroom schedule (see Figure 1) incorporated an array of reading and writing activities, integrated content area instruction, large group and small group activities, active and passive activities, and enrichment time.

Figure 1. Ms. May’s Class Schedule

\begin{tabular}{|c|c|}
\hline $8: 00-8: 30$ & Choice Time \\
\hline \multirow[t]{6}{*}{$8: 30-9: 00$} & Enrichment Class \\
\hline & Monday--Music \\
\hline & Tuesday--Physical Education \\
\hline & Wednesday--Music \\
\hline & Thursday--Reading and Writing Time \\
\hline & Friday--Reading and Writing Time \\
\hline $9: 00-10: 00$ & Repeated Read Aloud \\
\hline 10:00 - 10:15 & Recess and Snack \\
\hline \multirow[t]{4}{*}{ 10:15 - 11:30 } & Language Arts (group rotation or whole group) \\
\hline & Monday--Library (10:15 - 10:45) \\
\hline & Thursday--PE (10:45 - 11:15) \\
\hline & Friday--Computer Enrichment (10:45 - 11:15) \\
\hline \multirow[t]{2}{*}{$11: 30-12: 00$} & Mathematics \\
\hline & Wednesday--Social Skills \\
\hline $12: 00-12: 15$ & Journal Writing \\
\hline $12: 20-12: 50$ & Lunch \\
\hline $1: 00-1: 15$ & Bathroom and Story \\
\hline $1: 15-2: 15$ & Rest Time \\
\hline $2: 15-2: 30$ & Prepare to go home \\
\hline $2: 40$ & Car pool \\
\hline $2: 50$ & Busses \\
\hline 3:00 & YEP (Youth Enrichment Program—after school child care) \\
\hline
\end{tabular}

The floor plan depicted a center-oriented approach to kindergarten, where children were involved in a multitude of activities during particular times in the day. Upon entering Ms. May's classroom, the large number of children's books was immediately noticed. These trade books were a key element in all areas. The Book and Author Area, which contained an Author's Corner, was inviting to the students. The books were on low shelves so they were retrievable by these young children. There were also small plastic tubs filled with books by special authors. The author's name was included on the front of the tubs with some having 
symbols or other identifying characteristics, so that the children could easily clasp a tub and reread or browse through books by their favorite authors. Pictures of the author, biographical information, copies of his or her books, and book jackets of books written by the special author were positioned for students to peruse. There was a book display rack facing the children where big books and small books were displayed. This rack held books that had just been read by the teacher. There was also a section for books that children brought to school which they wanted Ms. May to read to the class or they wanted to share with their classmates. Tape recorders and mp3 players with stereo headphones were also available so that children could leisurely listen to audio books, many of which had already been read aloud by Ms. May. These opportunities for literacy engagement contributed to the overall classroom community being welcoming, personalized, and encouraging for student growth. Her students were exposed to literacy experiences and immersed in relevant and meaningful active ties for literacy development.

\subsection{Instructional Beliefs and Delivery}

Ms. May believed in integrating the curricula to respect the interrelationship between the four communication processes of reading, writing, speaking, and listening. All instruction and student activities were planned so that children could read, write, speak, and listen to others. Literacy events during the day included skill instruction, shared reading, journal writing, guided reading, independent reading, and literacy centers. May stated that "offering children multiple contexts to achieve literacy success is critical to the development of open readers." Seeking clarification, the investigator asked what she meant by 'open readers?' "Students who are not scared to pick up a book they have not seen before and try to read it," said May. She affirmed that students, even in kindergarten, who view books as learning opportunities, will more likely become lifelong learners.

Ms. May also planned thematic units based upon major concepts, which integrated the four communication processes and almost always included content area subject material. These units of study made meaningful connections for students and provided opportunities for transfer of skills. An example of a thematic unit in Ms. May's class was her unit about the ocean. She utilized children's literature such as the book, A House for Hermit Crab (Carle, 1991) and the big book, Life in the Sea (Curran, 1985). These texts served as the backbone of the unit. She introduced each book, posing investigative questions to assess background knowledge and level of familiarity with topics, extended students' knowledge by providing personal experiences and interesting facts about sea creatures, conducted picture walks while explicitly discussing projected unknown vocabulary, read and reread the texts while conducting think alouds, continually orally questioned students, and checked their original predictions with the content in the story after the reading. Her questions were literal, inferential, and application-oriented. May created charts that were later posted around the room to guide children in their inquiries into scientific concepts (e.g.s., underwater, fish, and crabs) they were interested in pursuing, and served as the basis for the unit of study to which was referred and reviewed daily.

These books and concepts about the ocean were integrated across the curriculum to include activities in reading, writing, mathematics, science, and social living. Relevant centers in the 
classroom reflected the integration of literacy skills into the content area theme. For example, in the science center, the children were able to observe several hermit crabs living in an aquarium. There was also a giant magnifying glass for exploring artifacts from the ocean for extended hands-on applications. Leveled texts and other appropriate books about oceanic life were strategically placed in the center. There were opportunities for the children to record their scientific observations within a science $\log$ so as to ensure student interaction, participation, and responsibility. Some may question the use of logs or journals in kindergarten; however, May promotes opportunities for children at various levels of proficiency. Some children are already able to write independently, while others need more support that is given by the teacher and fellow students. Ultimately, the goal is for the children to write with sensible phonetic spelling rather than conventional spelling of words for those not included on the word wall.

Students used real shells to classify and count sets in the mathematics center, both individually and with partners. Individual whiteboards were available for students to write numerals relating to sets and record other data. Having the ability to touch and manipulate the three-dimensional shells served to assist students in making abstract mathematical concepts into concrete principles. Moyer-Packenham, Salkind, and Bolyard (2008) found instruction that included investigative and skill-solidification techniques through the use of manipulatives assisted in students maintaining longer durations of focal attention. Moyer (2001) affirmed that features related to physical representations of mathematics encouraged relational thinking, learning, and content knowledge development.

The children articulated information for Ms. May to include on a chart that included words about the ocean and oceanic life, using many of their newly learned vocabulary words. This chart was placed in the writing center so that it would be available for the children's reference when writing in their journals or developing stories in the writing center. Relating their writing assignments to stories being read aloud, vocabulary and content information being studied, and topics being discussed was of utmost importance to Ms. May. Students were also reminded to leave a "meatball space" between each word and a "spaghetti space" between the letters within a word, so that they develop knowledge of conventions and other concepts about print along with their vocabulary content knowledge. Other writing activities included pattern sentences, predictable charts, write the room, journal writing, class books, daily news/morning message, and sticker stories.

As an independent art activity, the children painted crabs, reproducing the art work of Eric Carle in A House for Hermit Crab (1987). After painting the crabs and allowing them to dry, the students spent time at the art table developing fine motor skills by cutting out the crabs and assembling a collage in the style of Eric Carle. Then, these were placed on a bulletin board with related items and terminology related to the oceanic thematic unit to further develop the print-rich environment.

The teacher table area was an area where Ms. May worked with small groups of students in a directed instructional activity related to working with letters and sounds, word construction, phonemic awareness, or phonics. For example, she reread a book that had been read by the 
entire class earlier to a small group. Then the students and teacher completed extension activities emphasizing reading skills that Ms. May deemed important to this lesson. In one activity called "Create and Quiz," she regularly paired students giving each group one metal tray with a set of magnetic letters. Students took turns making vocabulary words or words related to the unit and quizzing each other on what word was created. Some students made statements that reflected they viewed the activity as a friendly competition while another summarized it quite well saying, "It's fun to learn with my friend."

Another popular activity in May’s classroom was “I Read, We Read, You Read.” Students loved listening to books being read aloud to them and orally chiming in with parts that they had already gained familiarity. However, it was the orderly and consistent behaviors of Ms. May that maximized students' reading development. Stories were originally read to them, then the entire class chorally read them, and then students read the texts individually. These familiar reads were well-suited for independent practice because students were less intimidated to take on the reading of a text as kindergarteners if they had already heard, seen, and recited the story. Not only did students comprehend the textual events but they began reading with appropriate pace and expression just as the teacher modeled.

During the group rotation part of the instructional day, the children were divided into three heterogeneous groups to rotate through the centers. There were three areas around which the students rotated: the teacher table where Ms. May provided direct instruction, the independent student activity table where students were involved in an independent project with occasional supervision by the special education paraprofessional, and the center areas that Ms. May prepared. She allowed the students to sign up on a chart for participation in the center areas on Monday and thereafter, students rotated to the other centers during the reading block. A sign-up process provided structure so that there were only two or three children in each center at a time, and gave students an authentic purpose for writing. Ms. May began by calling a group to her table. One group went to the independent student activity table, and another group signed up for the centers. Students worked in these locations for approximately 15 to 20 minutes. Then Ms. May signaled using a soft bell, and students rotated. This rotation occurred three times so all students had an opportunity to complete the activities in each instructional area. Ms. May changed the heterogeneous groups often so that students had the opportunity to work alongside all of their peers.

\section{Findings}

Through a critical examination of each aspect of this teacher's beliefs and behavior, this investigation furnished information regarding how she created a classroom environment conducive to learning as well as her instructional practices that led towards early literacy acquisition.

\subsection{Question One}

The first question investigated Ms. May’s interaction kindergarten students in her classroom. It was found that Ms. May managed student behavior to ensure a positive classroom atmosphere. The students were praised generously for appropriate behaviors. The negative 
behaviors of the students were redirected so they were on task and involved in productive activities. Routines and transitions were carefully manipulated so that few problems arose.

Ms. May reviewed regularly to check for understanding, clarified and provided guided practice when needed, and consistently questioned in a manner that encouraged higher level thinking. She routinely made real-world connections and related content to background experiences of the students so that learning was more meaningful. Ms. May's instructional techniques were varied to meet the needs of her students. Her use of instructional conversations was a pervasive theme throughout the classroom. Ms. May continually conversed with her students in all settings and situations as they discussed instructional topics. When appropriate, Ms. May personalized her instruction while exposing new words in the literature they were sharing, essentially leading to their understanding and usage of the new vocabulary (Nagy \& Scott, 2000). Furthermore, Ms. May made accommodations for both her special education inclusion students that differed from those she made for her regular education students. Her modifications and adaptations were a natural part of her instruction, geared towards meeting the individual needs of all students by appealing to multiple senses, using proximity, positive behavior reinforcement, and other intervention techniques.

\subsection{Question Two}

Question two addressed the behaviors exhibited by Ms. May that engaged students in the literacy processes of reading and writing. Ms. May read new texts and reread familiar texts to and with the children daily. Whole group activities involved big books, rhymes, poems, songs, and charts. May stated, "I allow and encourage students to read spontaneously because I believe that children are naturally curious and inquisitive, long to participate, need to stay active, and desire praise.” When sharing a book, Ms. May exposed students to whole texts, not merely text fragments, by reading the entire book at each sitting. "Students will only learn to read by doing it" was one of her common expressions and as a result, she planned situations daily that encouraged students to read, write, and engage in literacy activities.

To involve students further in quality literature and to develop targeted skills, Ms. May provided book extension activities for her students. They regularly participated in book talks to discuss texts, authors, and illustrators. Ms. May modeled writing for her students so they could learn processes and conventions (Schulze, 2006). She encouraged students to write for varied authentic purposes throughout each school day. Ms. May gave direct instruction to ensure student success with reading and writing activities. Explicit skill instruction was provided to individuals, small groups, and the whole class. Her classroom was always inviting and filled with print-rich materials and activities, including the innovative use of digital books via mp3 players (which was a favorite of her students). It was apparent even to visitors and casual observers that students were actively engaged in meaningful learning activities.

\subsection{Question Three}

Question three examined Ms. May's repeated read aloud strategy and her behaviors, as she encouraged students to react to books using this specific strategy. Analysis of the data 
indicated that there were few observable differences in how Ms. May encouraged students to react to books using this specific strategy as opposed to how she encouraged children to become engaged in literacy processes in general throughout the day. In other words, Ms. May used the same effective behaviors to encourage student engagement regardless of the literacy activity. However, several positive teacher and student behaviors emerged which indicated that the repeated read aloud strategy was an especially worthwhile activity. The positive aspects included: (a) probing and questioning planned by the teacher; (b) extending the vocabulary and concepts through conversations about each book in use; (c) student questioning of the teacher about the text and its contents; (d) more interaction during the read alouds by students than had been previously noted when Ms. May simply read a book without a planned book talk; (e) deeper understanding of the book and a more thorough comprehension of the book by the students; and (f) reading of words, sentences, or phrases from the text by most of the students on the third and fourth day of rereading the book. With some of the books used for the repeated read aloud strategy, all students could read parts of the text by the end of the five-day lesson sequence.

\subsection{Question Four}

Question four examined Ms. May's professional activities and relationships with her peers that contributed to her beliefs and practices. Data analysis showed that Ms. May was a professional teacher who attended conferences, read journals, worked actively on committees, continued to take professional development courses, and had a developed plan for personal growth. She continued to learn, shared with others, and took risks to accomplish her goals, as she served as a mentor to her fellow kindergarten teachers in the school district. By teaching learned techniques and strategies to others in the area, May claimed, "I developed into a much better educator for my kindergarteners by becoming more aware of why and how things work in the classroom."

\section{Discussion}

While these findings of Ms. May's behaviors were specifically reflective to her classroom setting, her effective practices were strongly supported by the literature. The National Association for the Education of Young Children (NAEYP) has promoted the use of developmentally appropriate practices in programs for four- and five-year olds for more than 30 years. Ms. May's classroom provided a model for the use of these age-appropriate practices. Following the recommendations of NAEYP, Ms. May viewed each child as unique with individual patterns of development. She planned lessons and activities that accommodated different levels of ability and learning styles. All interactions were intentional to build self-esteem in her young learners and to promote a positive feeling about reading and learning in general. Ms. May seated her students so they were working individually and in small groups, and provided multiple opportunities throughout the day for them to interact with various types of literature and writing and in other communicative activities.

Students in Ms. May's room were given many chances to view reading and writing holistically while also being instructed in skills such as letter names and sounds. Students experimented with writing; Ms. May encouraged drawing, copying, and attempted spelling. 
She integrated activities in the content areas with language-based, hands-on experiences. Differentiated instruction and modification of activities were routinely accomplished by Ms. May to meet the varying needs of all her students. The developmentally appropriate practices delineated by NAEYP were seen daily in Ms. May's classroom.

Morrow and O'Connor (1995) offered a list of constructs for emergent literacy to guide the development of a successful program for beginning reading. These constructs included: (a) focusing on the development of the whole child; (b) emphasizing an optimal learning environment; (c) promoting learning rather than teaching; (d) stressing the importance of adult/child social interactions; (e) urging meaningful, natural learning experiences; and (f) exhibiting concern for children's active participation in learning. Ms. May's lessons and activities followed these constructs. She created a classroom environment conducive to independent and group learning, while also recognizing and encouraging the importance of adult-child social interactions. Emphasis was placed on meaningful learning experiences, and Ms. May was concerned about supporting children's active participation in learning.

Ms. May's activities and centers provided daily opportunities for her students to be actively involved in interactive storybook readings. Her book talks with the children allowed them to observe an adult role model engaged in reading and helped develop critical vocabulary, word recognition, and comprehension skills. Ms. May involved all children in these activities regardless of ability level or identification. Even in selecting food at the lunchroom, her students would voluntarily engage in ordering "flamburgers," mimicking the initial letter manipulation activity in class.

With repeated readings, the students began to recognize sight words as well as gain meaning from the familiar stories. Data analysis showed that Ms. May built rereading opportunities into most activities involving texts. Ms. May and/or the students routinely reread books, alphabetic and blend charts, messages, excerpts, and poems. Her repeated read aloud strategy was also structured in a fashion to maximize the benefits of repeated reading and related educational outcomes.

Ms. May expressed high expectations for all her students. Since children tend to perform to the expectations of their teachers, Ms. May's expectations helped promote success in emergent literacy acquisition. Her expectations for special education inclusion students were as high as those for her regular education children. A report by a coalition of educational associations sponsored by the Council for Exceptional Children has suggested a set of principles for inclusion (Council for Exceptional Children, 1994) by which she followed. She maintained high standards for her students, herself, and other adults who worked with her children. Moreover, she communicated her high standards to all students and emphasized differing strategies or degrees to which educational outcomes were achieved by various students. Her inclusive classroom exhibited a feeling of belonging and acceptance and built a deep sense of community.

Ms. May’s teaching strategies were primarily research-based and provided authentic learning activities within a developmentally appropriate curriculum while infusing technologically to enhance student interest. She worked collaboratively with the special education inclusion 
teacher and instructional aide who assisted students needing extra help. Parents were considered partners in the classroom and became involved in implementing strategies and activities suggested by Ms. May. She provided physical modifications to ensure access and participation of all students.

Ms. May read aloud carefully selected, quality children's literature to: (a) promote enjoyment and appreciation of books, (b) extend a thematic unit, (c) model fluent oral reading, (d) develop vocabulary, (e) enhance listening comprehension, (f) link experiences to text, and (g) stimulate imagination. When Ms. May read to her students, she encouraged the development of these areas of emergent literacy. She believed that reading aloud to children was valuable, well-spent time, and as a result, it was a planned priority in her classroom.

\section{References}

Allor, J. H., \& McCathren, R. B. (2003). Developing emergent literacy skills through storybook reading. Intervention in School and Clinic, 39, 72-79.

Arbeau, K. A., \& Coplan, R. J. (2007). Kindergarten teachers' beliefs and responses to hypothetical prosocial, asocial, and antisocial children. Merrill-Palmer Quarterly, 53, 291-318.

Biemiller, A., \& Boote, C. (2006). An effective method for building vocabulary in primary grades. Journal of Educational Psychology, 98, 44-62.

Birch, S. H., \& Ladd, G. W. (1997). The teacher-child relationship and children's early school adjustment. Journal of School Psychology, 35, 61-79.

Bogdan, R. C., \& Biklen, S. K. (2006). Qualitative research for education: An introduction to theory and methods (4th ed.). Needham Heights, MA: Allyn and Bacon.

Byrne, B., \& Fielding-Barnsley, R. (1991). Evaluation of a program to teach phonemic awareness to young children. Journal of Educational Psychology, 83, 451-455.

Byrne, B., \& Fielding-Barnsley, R. (1993). Evaluation of a program to teach phonemic awareness to young children: A one year follow-up. Journal of Educational Psychology, 85, 104-111.

Byrne, B., \& Fielding-Barnsley, R. (1995). Evaluation of a program to teach phonemic awareness to young children: A two and three year follow-up and a new preschool trial. Journal of Educational Psychology, 87, 488-503.

Byrne, B., \& Fielding-Barnsley, R. (2000). Effects of preschool phoneme identity training after six years: Outcome level distinguished from rate of response. Journal of Educational Psychology, 92, 659-667.

Carle, E. (1991). A house for hermit crab. New York: Scholastic.

Chang, L. (2003). Variable effects of children's aggression, social withdrawal, and prosocial leadership as functions of teacher beliefs and behaviors. Child Development, 74, 535-548. 
Charlesworth, R. (1998a). Developmentally appropriate practice is for everyone. Childhood Education, 74, 274-282.

Charlesworth, R., Hart, C. H. Burts, D. C., \& DeWolf, M. (1993). The LSU studies: Building a research base for developmentally appropriate practice. In S. Reifel (Ed.), Perspectives on developmentally appropriate practice in advances in day care and early education (Vol. 5, pp. 3-28). Greenwich, CT: JAI.

Council for Exceptional Children. (1994). Twelve principles for successful inclusive schools. CEC Today, 1(2), 3-14.

Curran, E. (1985). Life in the sea. Mahwah, NJ: Troll.

Durkin, D. (1987). A classroom-observation study of reading instruction in kindergarten. Early Childhood Research Quarterly, 2, 275-300.

Fang, Z. (1996). A review of research on teacher beliefs and practices. Educational Research, 38, 47-65.

Fox, B. (2007). Word identification strategies: Building phonics into a classroom reading program ( $4^{\text {th }}$ ed.). Upper Saddle River, NJ: Prentice Hall.

Hamre, B. K., \& Pianta, R. C. (2001). Early teacher-child relationships and the trajectory of children's school outcomes through eighth-grade. Child Development, 72(2), 625-638.

Harris, K. K., Loyo, J. J., Holahan, C. K., Suzuki, R., \& Gottlieb, N. H. (2007). Cross-sectional predictors of reading to young children among participants in the Texas WIC Program. Journal of Research in Childhood Education, 21(1), 254-268.

Hatcher, P., Hulme, C. \& Ellis, A.W. (1994). Ameliorating early reading failure by integrating the teaching of reading and phonological skills: The phonological linkage hypothesis. Child Development, 65, 41-57.

Huffman, L. R., \& Speer, P. W. (2000). Academic performance among at-risk children: The role of developmentally appropriate practice. Early Childhood Research Quarterly, 15(2), 167-184.

Justice, L. M., Mashburn, A. J., Hambre, B. K., \& Pianta, R. C. (2008). Quality of language and literacy instruction in preschool classrooms serving at-risk pupils. Early Childhood Research Quarterly, 23(1), 51-68.

Kamil, M. L., \& Hiebert, E. H. (2005). Teaching and learning vocabulary: Perspectives and persistent issues. In E. H. Hiebert \& M. L. Kamil (Eds.), Teaching and learning vocabulary: Bringing research to practice (pp. 1-23). Mahwah, NJ: Erlbaum.

Marcon, R. A. (2002). Moving up the grades: Relationship between preschool model and later school success. Early Childhood Research and Practice, 4(1), 1-20.

McMullen, M. B. (1999). Characteristics of teachers who talk the DAP talk and walk the DAP walk. Journal of Research in Childhood Education, 13(2), 216-230. 
McGee, L. M., \& Morrow, L. M. (2005). Teaching literacy in kindergarten. New York: The Guilford Press.

Metsala, J. L., \& Ehri, L. C. (Eds.). (1998). Word recognition in beginning literacy. Philadelphia, PA: Lawrence Erlbaum Associates.

Morris, D., Bloodgood, J. W., Lomax, R. G., \& Perney, J. (2003). Developmental steps in learning to read: A longitudinal study in kindergarten and first grade. Reading Research Quarterly, 38(3), 302-328.

Morrow, L., \& O’Connor, E. (1995). Literacy partnerships for change with at-risk kindergarteners. In R. Allington \& S. Walmsley (Eds.), No quick fix: Rethinking literacy programs in America's elementary schools (pp. 97-115). New York: Teachers College Press and Newark, DE: International Reading Association.

Moyer, P. S. (2001). Are we having fun yet? How teachers use manipulatives to teach mathematics. Educational Studies in Mathematics, 47(2), 175-197.

Moyer-Packenham, P. S., Salkind, G., \& Bolyard, J. J. (2008). Virtual manipulatives used by K-8 teachers for mathematics instruction: Considering mathematical, cognitive, and pedagogical fidelity. Contemporary Issues in Technology and Teacher Education [Online serial], 8(3), [Online] Available: www.citejournal.org/vol8/iss3/mathematics/article1.cfm

Muijs, D., \& Reynolds, D. (2002). Teachers' beliefs and behaviors: What really matters? Journal of Classroom Interaction, 37, 3-15.

Nagy, W. E., \& Scott, J. A. (2000). Vocabulary processes. In M. L. Kamil, P. B. Mosenthal, P. D. Pearson, \& R. Barr (Eds.), Handbook of reading research: Vol. 3 (pp. 269-284). Mahwah, NJ: Lawrence Erlbaum.

National Institute of Child Health and Human Development. (2000). Report of the National Reading Panel. Teaching children to read: An evidence-based assessment of the scientific research literature on reading and its implications for reading instruction (NIH Publication No. 00-4769). Washington, DC: U.S. Government Printing Office.

Neuharth-Pritchett, S. (2001, April). Recommendations for kindergarten retention: Assessing classroom practices and their relationship to non-promotion decisions. Paper presented at the annual meeting of the American Educational Research Association, Seattle, WA.

Neuman, S. B., \& Dickinson, D. K. (Eds.). (2003). Handbook of early literacy research: Vol. 1. New York: The Guilford Press.

Owocki, G., \& Goodman, Y. M. (2002). Kidwatching: Documenting children's literacy development. Portsmouth, NH: Heinemann.

Parker, A., \& Neuharth-Pritchett, S. (2006). Developmentally appropriate practice in kindergarten: Factors shaping teacher beliefs and practice. Journal of Research in Childhood Education, 21(1), 63-76. 
Patton, M. Q. (2001). Qualitative evaluation and research methods ( $3^{\text {rd }}$ ed.). Newbery Park, CA: Sage Publications.

Rasinsky, T., Blanchowicz, C., \& Lems, K. (Eds.). (2005). Fluency instruction: Research-based best practices. New York: The Guilford Press.

Richman, A. W., \& Colombo, J. (2007). Joint book reading in the second year and vocabulary outcomes. Journal of Research in Childhood Education, 21(3), 242.

Rimm-Kaufman, S., La Paro, K., Downer, J., \& Pianta, R. (2005). The contribution of classroom setting and quality of instruction to children's behavior in the kindergarten classroom. Elementary School Journal, 105(4), 377-394.

Rog, L. J. (2001). From early literacy instruction in kindergarten. Newark, NJ: International Reading Association.

Schneider, W., Roth, E., \& Ennemoser, M. (2000). Training phonological skills and letter knowledge in children at risk for dyslexia: A comparison of three kindergarten intervention programs. Journal of Educational Psychology, 2, 284-295.

Schulze, A. C. (2006). Helping children become readers through writing: A guide to writing workshops in kindergarten. Newark, DE: International Reading Association.

Spradley, J. P. (1980). Participant observation. Orlando, FL: Holt, Rinehart, and Winston.

Stahl, S. A. (Ed.). (2006). Reading research at work: Foundations of effective practice. New York: The Guilford Press.

Strickland, D. S. (2001). Preparing our teachers: Opportunities for new reading instruction. Washington, DC: Joseph Henry Press.

Teale, W., \& Yokota, J. (2000). Beginning reading and writing: Perspectives on instruction. In D. S. Strickland and L. M. Morrow (Eds.), Beginning reading and writing. New York: Teachers College Press and International Reading Association.

Torgesen, J. (2004, Fall). Preventing early reading failure. American Educator. Retrieved February 28, 2009 [Online] Available: http://www.aft.org/pubs-reports/american_educator/iss ues/fall04/ reading.htm

Williams, J. P. (2002). Reading comprehension strategies and teacher preparation. In A. E. Farstrup, \& S. Samuels (Eds.), What research has to say About reading instruction (pp. 243-260). Newark, DE: International Reading Association.

Woude, A. V. (2004). Reading for every child fluency, grade k. Grand Rapids, MI: Instructional Fair.

Vartuli, S. (1999). How early childhood teacher beliefs vary across grade level. Early Childhood Research Quarterly, 14, 489-514. 